\title{
e Antigen and antibody in outbreaks of hepatitis B in two renal dialysis units
}

\author{
P. E. GIBSON
}

From the Virus Reference Laboratory, Central Public Health Laboratory, Colindale Avenue, London NW9 $5 H T$

SUMMARY In two renal dialysis units which had outbreaks of hepatitis B, patients were studied for the presence of $e$ antigen and antibody. In one unit, in which the illness was mild and most of the patients $(78 \%$ ) became carriers of $\mathrm{HBsAg}$, all but one patient had e antigen. Most of the $\mathrm{HBsAg}$ carriers had persisting e antigen and most of the transient patients had also transient e antigen. In the other unit, in which the illness was more severe, none of the patients became a carrier. Only $30 \%$ had e antigen during the acute phase of illness and $40 \%$ developed anti-e just before clearing HBsAg. It seems possible that the differences between these two units may reflect strain differences in the infectivity of hepatitis B virus.

The e antigen/antibody system was first described by Magnius and Espmark (1972), who suggested that the presence of e antigen might indicate infectivity while the antibody occurred only in non-infectious HBsAg positive sera. The correlation of e antigen with large numbers of 'Dane' particles, and its absence in sera containing no 'Dane' particles (Nielsen et al., 1974; Neurath et al., 1976), also seems to suggest a relationship to infectivity. Neurath et al. (1976) suggested that $e$ antigen is present as an additional antigenic site on the surface of the 'Dane' particles and tubular forms of $\mathrm{HBsAg}$ as well as in the form of a soluble antigen. Nielsen et al. (1974) suggested that it might be a valuable prognostic marker because it was present in the sera of $58 \%$ of cases of acute hepatitis B which progressed to chronic hepatitis or cirrhosis.

In the present study, the presence was determined of $e$ antigen and antibody in sera from patients in two renal dialysis units in which the outbreaks of hepatitis B (during 1969-71) were quite different (Polakoff et al., 1972). In dialysis unit A, 32 of the infected patients became carriers of HBsAg. Of these, consecutive serum samples were available from 27. In dialysis unit $B$, none of the infected patients became a carrier. Consecutive serum samples were available from all 10 individuals.

\section{Material and methods}

Sera taken from patients with hepatitis B infection in the two renal dialysis units were examined for $e$

Received for publication 31 January 1977 antigen and antibody. In unit $\mathbf{A}$, consecutive serum samples were available from the patients for periods of five months to five years after the onset of antigenaemia. In unit $B$, serum samples were available from the patients from the onset of antigenaemia until they cleared HBsAg. Serum samples taken just before hepatitis $B$ infection in the patients of both units were also examined for e and anti-e.

All the samples were first tested by immunoelectroosmophoresis (IEOP) for HBsAg activity.

The immunodiffusion test was used to detect $\mathrm{e}$ antigen and antibody. The gel consisted of $0.9 \%$ agarose (Indubiose, l'Industrie Biologique Francaise) in tris buffer. The test was performed in $5 \mathrm{~cm}$ Petri plates with the gel $3 \mathrm{~mm}$ thick. Six wells were cut surrounding a central well, each $6 \mathrm{~mm}$ in diameter with approximately $10 \mathrm{~mm}$ between the centres of the wells. Each well was twice filled with sera.

The anti-e serum was obtained from a blood donor who was a carrier of HBsAg. The standard e antigen was serum obtained from a carrier of $\mathrm{HBsAg}$ who had chronic liver disease. Reference e antigen and anti-e sera were kindly supplied by Dr J. O. Nielsen (Copenhagen) and $\mathrm{Dr}$ L. O. Magnius (Stockholm).

\section{Results}

The frequency of e antigen and antibody in the HBsAg carriers of two renal dialysis units is shown in Table 1. In unit A, in which most of the individuals with HBs antigenaemia progressed to become carriers of $\mathrm{HBsAg}$, all of those followed up except one 
Table 1 Presence of $e$ antigen and antibody in two dialysis unit outbreaks of hepatitis $B$

\begin{tabular}{lcccc}
\hline Category & Total & Persisting & Transient e & Anti-e \\
\hline Unit A & & & & \\
HBsAg carriers & $21(78 \%)$ & 19 & 2 & 0 \\
Transient HBsAg & $6(22 \%)$ & 0 & 5 & 1 \\
Total & 27 & 19 & 7 & 1 \\
Unit B & & & 1 \\
HBsAg carriers & 0 & 0 & 0 & 0 \\
Transient HBsAg & $10(100 \%)$ & 0 & 3 & 0 \\
Total & 10 & 0 & 3 & 3 \\
\hline
\end{tabular}

Table 2 Duration of $e$ antigen and antibody in postinfection sera from transient carriers of hepatitis $B$ in two dialysis unit outbreaks

\begin{tabular}{|c|c|c|c|c|c|c|c|c|c|}
\hline \multirow[t]{2}{*}{ Unit } & \multirow{2}{*}{$\begin{array}{l}\text { Duration of } \mathrm{HBs} \\
\text { antigenaemia }\end{array}$} & \multirow[t]{2}{*}{ Number } & \multicolumn{3}{|c|}{ Detectable e at (months) } & \multicolumn{3}{|c|}{ Detectable anti-e at (months) } & \multirow{2}{*}{$\begin{array}{l}\text { Neither } \\
\text { e nor anti-e }\end{array}$} \\
\hline & & & 1 & 2 & 3 & 1 & 2 & 3 & \\
\hline $\begin{array}{l}\text { A } \\
\text { (6 cases) }\end{array}$ & $\begin{array}{l}<1 \text { month } \\
1-2 \text { months } \\
2-3 \text { months }\end{array}$ & $\begin{array}{l}1 \\
4 \\
1\end{array}$ & $\begin{array}{l}1 \\
3 \\
1\end{array}$ & $\begin{array}{l}- \\
2 \\
1\end{array}$ & $\frac{-}{1}$ & $\begin{array}{l}0 \\
0 \\
0\end{array}$ & $\begin{array}{l}- \\
0 \\
0\end{array}$ & $\begin{array}{l}- \\
1 * \\
0\end{array}$ & $\begin{array}{l}0 \\
1 \\
0\end{array}$ \\
\hline \multirow[t]{2}{*}{$\begin{array}{l}\text { B } \\
\text { (10 cases) }\end{array}$} & $\begin{array}{l}\text { Total } \\
<1 \text { month } \\
\text { 1-2 months } \\
2-3 \text { months }\end{array}$ & $\begin{array}{l}5 \\
4 \\
1\end{array}$ & $\begin{array}{l}3 \\
\mathbf{0} \\
\mathbf{0}\end{array}$ & $\begin{array}{l}- \\
0 \\
0\end{array}$ & $\overline{-}$ & $\begin{array}{l}1 \\
0 \\
0\end{array}$ & $\begin{array}{l}- \\
2 \\
0\end{array}$ & $\overline{-}$ & $\begin{array}{l}1 \\
2 \\
0\end{array}$ \\
\hline & Total & 10 & 3 & 0 & 0 & & & & \\
\hline
\end{tabular}

*This specimen was HBsAg negative

had e antigen in their sera. No anti-e was detected in the carriers and only one of those with transient HBsAg had detectable anti-e. In this individual e antigen was detected within the first month of $\mathrm{HBs}$ antigenaemia. At two months the serum was HBsAg positive and e negative. At three months the serum was HBsAg negative and contained anti-e.

In unit $B$, in which no patient became a carrier of HBsAg, $30 \%$ of the transient cases had detectable e while $40 \%$ had detectable anti-e. In these patients (Table 2) e antigen was found only within the first month of antigenaemia and anti-e was found only just before the disappearance of HBsAg from the serum. In this unit, the presence of e antigen did not imply a longer period of HBs antigenaemia. In fact, in all three patients in whom e antigen was detected, HBs antigenaemia lasted for less than one month while three or the four patients in whom anti-e was detected had HBsAg in the sera for periods longer than one month. In contrast, the transient HBsAg carriers in unit $\mathbf{A}$ in whom $\mathrm{e}$ was detected had detectable e for almost the complete duration of their HBs antigenaemia. There appeared to be no difference in the duration of HBs antigenaemia in the transient carriers between the two units although $e$ antigen did tend to persist longer in unit $\mathbf{A}$.

The presence or absence of $e$ antigen in the serum was not related to the titre of $\mathrm{HBsAg}$, as seen in Table 3.

Table 3 Non-correlatior of $e$ antigen with the titre of HBsAg in different serum samples

\begin{tabular}{lll}
\hline Serum & e Ag & HBsAg titre (IEOP) \\
\hline 1 & + & 64 \\
2 & - & 32 \\
3 & + & 4 \\
4 & + & 16 \\
5 & - & 8 \\
6 & - (anti-e) & 16 \\
7 & - & 16 \\
8 & - (anti-e) & 16 \\
9 & + & 0 \\
& & (detectable only by \\
\end{tabular}

\section{Discussion}

Many studies of the e antigen/antibody system have related the features of individual cases to the presence $\stackrel{\odot}{+}$ of e antigen or antibody (Eleftheriou et al., 1975; El 0 Sheikh et al., 1975; Feinman et al., 1975; Nordenfelt and Kjellen, 1975; Vogten et al., 1976). This report is concerned with the epidemiological significance of the e system. 
The two dialysis unit outbreaks have previously been compared (Polakoff et al., 1972). In unit A, the classical pattern was observed, many of the patients experiencing very mild symptoms of hepatitis at the time $\mathrm{HBsAg}$ was first detected. Of the infected patients, $78 \%$ became established HBsAg carriers and all of these had e antigen detectable from the acute phase onwards. In only two cases $(10 \%)$ did the e antigen disappear. Similar findings have been reported by Nordenfelt et al. (1975). In their series, most of the patients showed histological evidence of chronic hepatitis. Of the six patients in unit A who cleared HBsAg five had e antigen at the onset of hepatitis. From this it appears that determinations of e have no prognostic value in prediciting the outcome of individual cases.

In unit B there were fewer patients and these experienced much more acute symptoms of hepatitis than is expected in dialysis unit outbreaks. Moreover, all cleared the antigen within four months of onset. Only $30 \%$ of the infected patients in the unit produced e antigen during their illness. Contrary to the results of Norkrans et al. (1976) in their study of acute hepatitis $B$, the presence of e antigen was not related to a longer duration of HBs antigenaemia.

There were marked differences in the detection of e antibody in these outbreaks. Only one patient in unit $A$ produced anti-e shortly after the appearance of e antigen, and both were present transiently. In unit B, however, four of the 10 infected patients produced anti-e transiently just before they finally cleared HBsAg. It is unlikely that the difference in the courses of the hepatitis B outbreaks is due to different methods of selection or treatment of patients, nor can it be attributed to a difference in the subtype since ay was involved in both units. However, it does seem that $e$ antigen and antibody determinations may be useful in predicting the course of dialysis outbreaks.

These results also suggest that the occurrence of e antigen or antibody could be related to the nature of the infecting strain rather than to the individual patient's response.
References

Eleftheriou, N., Thomas, H. C., Heathcote, J., and Sherlock, S. (1975). Incidence and clinical significance of e antigen and antibody in acute and chronic liver disease. Lancet 2, 1171-1173.

El Sheikh, N., Woolf, I. L., Galbraith, R. M., Eddleston, A. L. W. F., Dymock, I. W., and Williams R. (1975). e Antigen-antibody system as indicator of liver damage in patients with hepatitis B antigen. British Medical Journal 4, 252-253.

Feinman S. V., Berris, B., Sinclair, J. C., Wrobel, D. M., Murphy, B. L., and Maynard, J. E. (1975). e Antigen and anti-e in HBsAg carriers. Lancet, 2, 1173-1174.

Magnius, L. O. and Espmark, J. A. (1972). New specificities in Australia antigen positive sera distinct from the Le Bouvier determinants. Journal of Immunology, 109, 1017-1021.

Neurath, A. R., Trepo, C., Chen, M., and Prince, A. M. (1976). Identification of additional antigenic sites on Dane particles and the tubular forms of hepatitis B surface antigen. Journal of General Virology, 30, 277285.

Nielsen, J. O., Dietrichson, O., and Juhl, E. (1974). Incidence and meaning of the ' $e$ ' determinant among hepatitis-B-antigen positive patients with acute and chronic liver diseases. Lancet, 2, 913-915.

Nordenfelt, E. and Kjellen, L. (1975). Dane particles, DNA polymerase, and $e$ antigen in two different categories of hepatitis B antigen carriers. Intervirology, 5, 225-232.

Nordenfelt, E., Lindholm, T., and Henrikson, H. (1975). The relationship between hepatitis $\mathrm{B}$ antigen, $\mathrm{e}$ antigen and liver-pathology in patients treated with dialysis. Scandinavian Journal of Urology and Nephrology, 9, 277281.

Norkrans, G., Magnius, L., and Iwarson, S. (1976). e Antigen in acute hepatitis B. British Medical Journal, 1, 740-742.

Polakoff, S., Cossart, Y. E., and Tillett, H. E. (1972). Hepatitis in dialysis units in the United Kingdom. British Medical Journal, 3, 94-99.

Vogten, A. J. M., Schalm, S. W., Summerskill, W. H. J., Smith, J. L., Gitnick, G. L., Murphy, B. L., and Maynard, J. E. (1976). Behaviour of e antigen and antibody during chronic active liver disease. Relation to $\mathrm{HB}$ antigen-antibody system and prognosis. Lancet, 2, 126-128. 